\title{
Gene expression in the intertidal mussel Mytilus californianus: physiological response to environmental factors on a biogeographic scale
}

\author{
Sean P. Place, Michael J. O'Donnell, Gretchen E. Hofmann* \\ Department of Ecology, Evolution and Marine Biology, University of California Santa Barbara, Santa Barbara, \\ California 93106-9610, USA
}

\begin{abstract}
We used a cDNA microarray to profile gene expression in the intertidal mussel Mytilus californianus across major portions of its biogeographic range. Overall, the expression pattern for the majority of genes assessed in this study varied significantly as a function of collection site and provides support for the hypothesis that the physiological response to emersion is distinct across populations of $M$. californianus. Gill tissue was dissected from adult, fieldacclimatized $M$. californianus collected from 4 sites across $17^{\circ}$ of latitude along the west coast of North America. First-strand cDNA prepared from 5 biological replicates from each site were competitively hybridized to a 2496 feature cDNA microarray. Gene expression patterns in mussels from Strawberry Hill, Oregon, displayed a unique expression phenotype that was distinct from the other 3 mussel populations sampled. In contrast, mussels sampled from Bamfield, British Columbia, and Jalama Beach, California, showed similar expression patterns. These data suggest that the physiological response of $M$. californianus to abiotic factors, such as temperature, cannot be predicted by a simple latitudinal gradient. This study highlights the usefulness of genomicsbased approaches in assessing physiological responses to environmental variation across large spatial scales.
\end{abstract}

KEY WORDS: Environmental genomics $\cdot$ Mytilus californianus · DNA microarray · Biogeography · Gene expression · Species range · Intertidal invertebrates . Mussel

Resale or republication not permitted without written consent of the publisher

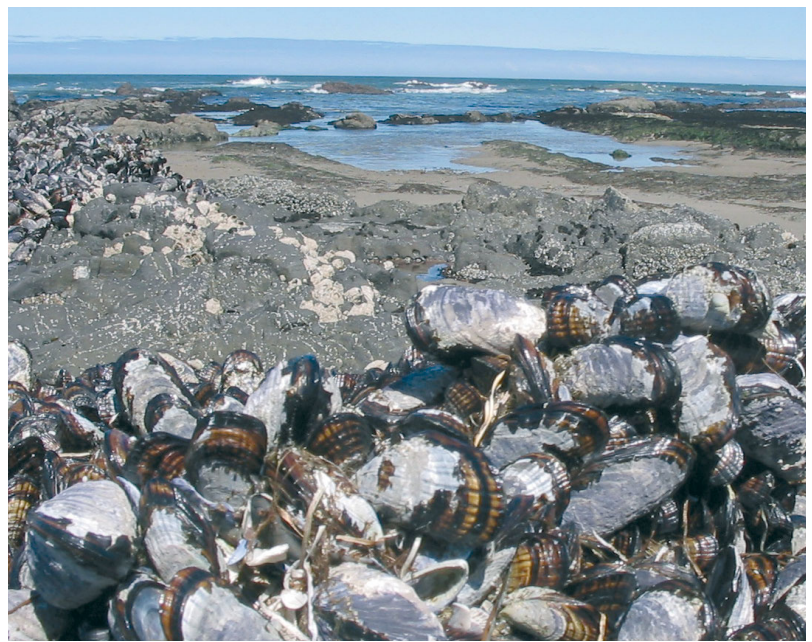

Gaping mussels in the intertidal zone at Strawberry Hill, Oregon, USA, a suspected ecological hotspot with high temperature stress for mussels during summer emersion.

Photo: Gretchen E. Hofmann

\section{INTRODUCTION}

Understanding the mechanisms that set species' range limits has long been a focus of ecological study in marine ecosystems (Spicer \& Gaston 1999). Given the expected alterations in species distributions and abundances that will be driven by climate change-related factors (Parmesan \& Yohe 2003), the need to understand these factors and to identify the physiological plasticity of organisms across their entire range has emerged as an urgent research need. Entering into this 
endeavor, physiological ecologists bring to these questions an assortment of tools to understand relevant performance variation at scales smaller than the whole organism. Recently, genomics-based approaches have allowed a unique view into the mechanisms underlying suites of ecological processes. Notably, transcriptomicsthe measurement of all mRNAs in a biological sampleis quickly emerging in marine ecology, enhancing our understanding of many important ecological and physiological processes in marine systems (for reviews see Hofmann et al. 2005, Wilson et al. 2005, Dupont et al. 2007, Hofmann \& Place 2007). The ability to profile the expression patterns of numerous genes at once is expanding investigations into ecological processes ranging from the mechanisms that maintain coral/algal symbioses (Rodriguez-Lanetty et al. 2006) to understanding mechanisms underlying physiological tolerances (Podrabsky \& Somero 2004, Buckley et al. 2006, Teranishi \& Stillman 2007) or for detection of disease in commercially important species (Dhar et al. 2003, Cunningham et al. 2006, Morrison et al. 2006).

Here, we present a study that integrates genomics, physiology, and marine ecology to explore the gene expression patterns in the mussel Mytilus californianus on a macroecological scale across the biogeographical range of this important intertidal species. Physiological ecologists have often sought to link the internal processes of organisms with environmental factors controlling those processes in order to understand the broader distributions of populations and species. The bulk of such work has, until recently, been accomplished using small spatial scales, often involving laboratory manipulations of a single environmental stressor (e.g. Bertness et al. 1999, Somero 2002, Harley \& Helmuth 2003). Additionally, of the studies that have examined physiological performance across large scales, most have employed relatively basic proxies such as RNA:DNA ratios (Byers 2005), growth rates (Levinton \& Monahan 1983, Yamahira \& Conover 2002), or reproductive output (Lewis 1986, Lester et al. 2007). Although such work has led to great advances in our understanding of how individuals perform in response to specific environmental conditions, the next challenge is to enhance understanding of the impact of multiple environmental parameters on physiological performance of populations across large spatial scales. To this end, we have taken initial steps to investigate natural variation in acclimatization responses of intertidal mussels by assessing their transcriptome - the set of all mRNAs in a given cell population - at a specific window in time. One can argue that if regulation of mRNA expression confers phenotypic variation, we would expect this variation in expression to be reflected within distinct populations of species inhabiting highly variable environments. For this purpose,
Mytilus californianus provides a unique non-model system for these investigations. M. californianus has been especially well studied, both in terms of its thermal physiology and its role in structuring intertidal communities (reviewed in Menge \& Branch 2001). Furthermore, one of the most well-studied parameters structuring these communities is that of the temperature profile experienced by these organisms during daily cycling of aerial emersion. Interestingly, the pattern of variation experienced by these organisms is not predictable by a simple latitudinal cline, and thus it becomes more important to examine organismal function on a genome-wide scale.

Temperature patterns measured along the intertidal zone of the Pacific coast, in addition to mussel body temperature models developed by Helmuth and colleagues, indicate that populations of Mytilus californianus should have very different physiological responses along the latitudinal distribution of this species (Helmuth et al. 2002, 2006). More importantly, it has been suggested that these responses should not vary linearly with latitude, but should exhibit a more complex pattern governed by the timing of low tides, with stress responses more evident at sites in Washington and Oregon than at sites located further south during early summer months (Helmuth et al. 2002, 2006). By examining the natural expression state of mussel populations from sites with known thermal variation, we can predict that a strong thermal acclimatization imprint will be seen for stress responsive pathways at specific latitudes based on previous body temperature measurements (Helmuth et al. 2002, 2006) and biochemical indicators of stress (Sagarin \& Somero 2006). Additionally, genome-wide analyses of $M$. californianus populations may highlight the interplay of multiple physiological responses outside of the predicted thermal response. For instance, if mussel populations in Oregon are indeed more thermally stressed than other populations, we would predict greater energy allocation to processes involved in maintaining protein homeostasis for these individuals. Conversely, we would also predict to see evidence for a reduction of energetically costly processes associated with growth, proliferation, and gametogenesis in individuals from this particular population. On the other hand, since the samples were obtained during low tide, we might also predict to see a similar depression in metabolic and aerobic capacity across all sites, since mussels enter a quiescent state during emersion events. Thus, from a broader perspective, this approach could potentially yield a 'transcriptome fingerprint' of the mechanisms driving biogeographic patterning for a particular location.

In the present paper we describe the application of a newly constructed cDNA microarray for Mytilus californianus to explore a range of physiological pathways 
in an effort to assess the usefulness of large-scale gene expression screening in addressing major macroecological questions. Using a combination of gene expression profiling and quantitative $\mathrm{PCR}$, we provide support for the hypothesis that the physiological response of $M$. californianus does not vary linearly as a function of latitude and that individuals sampled from the Oregon population show distinct changes in several physiological pathways. These results give the first look at variations in gene expression between organisms spread over $17^{\circ}$ of latitude along the west coast of North America and provide a proof of the concept for the application of genomics techniques to assist in the understanding of complex, large-scale ecological questions.

\section{MATERIALS AND METHODS}

Sample collection. Samples of Mytilus californianus were collected from 4 sites along the west coast of North America during the same low-tide series that occurred from 6 to 15 July 2006. Sampling sites are shown in Fig. 1, and their coordinates are listed in Table 1. At each sampling location, the vertical extent of the mid-intertidal zone was estimated visually, and 12 ind. with minimum/maximum shell lengths of 40 to $60 \mathrm{~mm}$ were randomly chosen from the center of a dense mussel bed. Due to the field resources required to sample so many sites simultaneously, we were not able to survey the actual tidal heights of our sampling locations. Individuals sampled were separated by a distance of $1 \mathrm{~m}$. Approximately $200 \mathrm{mg}$ of mussel gill was immediately dissected out and placed in $1 \mathrm{ml}$ of RNAlater (Ambion) and treated according to the manufacturer's protocol. Briefly, samples were held at $4^{\circ} \mathrm{C}$ while being transported to our home institution in Santa Barbara, CA, where they were then removed from the RNAlater and stored at $-80^{\circ} \mathrm{C}$ until used for analysis.

RNA extraction. Total RNA from approximately $100 \mathrm{mg}$ of frozen tissue was extracted using TRIzol (Invitrogen) following the manufacturer's recommendations. Following isolation of total RNA, the RNA was further cleaned by resuspending it in $0.1 \mathrm{ml}$ of diethyl procarbonate (DEPC)-treated water and adding $0.3 \mathrm{ml}$ of $6 \mathrm{M}$ guanidine $\mathrm{HCl}$ and $0.2 \mathrm{ml}$ of $100 \%$ ethylalcohol (EtOH). The entire volume was loaded onto a spin column (Ambion) and centrifuged for $1 \mathrm{~min}$ at $12000 \times \mathrm{g}$ at $4^{\circ} \mathrm{C}$. Flow-through was discarded, and filters were washed twice with $0.2 \mathrm{ml} 80 \% \mathrm{EtOH}$. RNA was eluted off of the filters twice with $0.1 \mathrm{ml}$ of DEPC-treated water. RNA was precipitated by the addition of $0.1 \mathrm{vol}$ of $3 \mathrm{M}$ sodium acetate ( $\mathrm{pH} 5.0$ ) and $2.5 \mathrm{vol}$ of $100 \%$ $\mathrm{EtOH}$, mixed by inversion of tubes and placed at $-80^{\circ} \mathrm{C}$

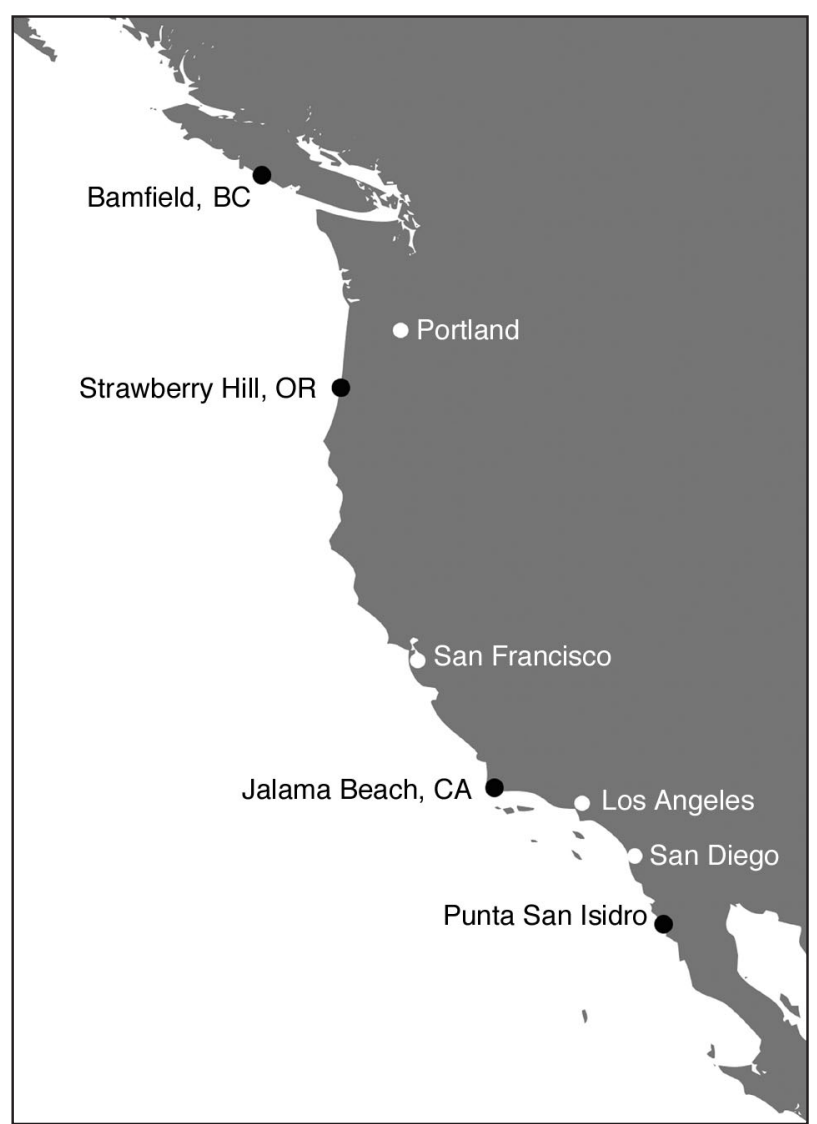

Fig. 1. Collection sites $(\bullet)$ and abbreviations for the present study. Punta San Isidro, Mexico: Baja-MX; Jalama Beach, California: JB-CA; Strawberry Hill, Oregon: SH-OR; Bamfield, British Columbia: Bamf-BC

for $1 \mathrm{~h}$. After this period, tubes were centrifuged at $12000 \times g$ for $20 \mathrm{~min}$ at $4^{\circ} \mathrm{C}$. Pellets were washed twice with $80 \%$ EtOH and resuspended in $30 \mu \mathrm{l}$ of DEPCtreated water. Final RNA concentrations were determined using a ND-1000 UV/visible spectrometer (NanoDrop Technologies). Only RNA samples with a 260:280 ratio of $\geq 1.9$ were used for this analysis.

Gene expression profiling with cDNA microarrays. Microarray analysis was performed utilizing a 2496 feature cDNA array constructed from a cDNA library developed in the laboratory of George N. Somero at the Hopkins Marine Station of Stanford University. Briefly, the cDNA library was prepared from different tissues (gill, adductor muscle, and mantle) of adult Mytilus californianus individuals exposed to a variety of stressors (heat, cold, emersion, hypoxia, hypoosmolality, cadmium, and low $\mathrm{pH}$ ) to induce enrichment of the mRNA pool for as many stress-responsive genes as possible (Gracey \& Somero unpubl. data). The data discussed in the present paper have been deposited in the National Center for Biotechnolgy Information (NCBI) Gene Expression Omnibus (GEO; 
Table 1. Mytilus californianus. Field-acclimatized gill tissue from $M$. californianus was collected at 4 sites spanning 17 degrees of latitude along the west coast of North America

\begin{tabular}{|c|c|c|c|}
\hline Abbreviation & Site & Latitude & Longitude \\
\hline Baja-MX & Punta San Isidro, Mexico & $31^{\circ} 17^{\prime} \mathrm{N}$ & $116^{\circ} 24^{\prime} \mathrm{W}$ \\
\hline JB-CA & Jalama Beach, Santa Barbara, CA & $34^{\circ} 29^{\prime} \mathrm{N}$ & $120^{\circ} 29^{\prime} \mathrm{W}$ \\
\hline SH-OR & Strawberry Hill, OR & $44^{\circ} 15^{\prime} \mathrm{N}$ & $124^{\circ} 7^{\prime} \mathrm{W}$ \\
\hline Bamf-BC & Bamfield, BC, Canada & $48^{\circ} 49^{\prime} \mathrm{N}$ & $125^{\circ} 09^{\prime} \mathrm{W}$ \\
\hline
\end{tabular}

www.ncbi.nlm.nih.gov/geo/) and are accessible through GEO Series Accession Number GSE8935.

For the competitive hybridizations, total RNA was extracted as previously described from the gill tissue of 10 ind. collected from a site in California not used in the present study, which were laboratory-acclimated at $13^{\circ} \mathrm{C}$ for $3 \mathrm{wk}$, but otherwise untreated, and were pooled for use as a source of reference RNA. It was against this reference sample that the values from the field-acclimatized samples were initially normalized (see Podrabsky \& Somero 2004, Buckley et al. 2006). Ten micrograms of total RNA from 5 ind. at each site was reverse transcribed (RT) to cDNA, using anchored oligo(dT15) primers and amino-allyl dUTP. The RNA template was removed from the RT reactions by incubating at $70^{\circ} \mathrm{C}$ for $15 \mathrm{~min}$ in $0.2 \mathrm{mM} \mathrm{NaOH}$ and $0.1 \mathrm{mM}$ EDTA. Single-stranded cDNA was EtOH precipitated at $-20^{\circ} \mathrm{C}$ for $1 \mathrm{~h}$, washed once with $70 \% \mathrm{EtOH}$, and re-suspended in $10 \mu \mathrm{l}$ of $100 \mathrm{mM}$ sodium bicarbonate (pH 9.0). Each sample was labeled with either Cy3 (reference samples) or Cy5 (experimental) cyanine monoreactive dye (GE Healthcare), prepared in $100 \mu \mathrm{l}$ of dimethylsulfoxide (DMSO). cDNA was incubated with $5 \mu \mathrm{l}$ of either Cy3 or Cy5 for $1 \mathrm{~h}$ at room temperature in the dark. The fluorescently labeled CDNAs were cleaned by passing over PCR purification columns (Qiagen) and eluted in $33 \mu \mathrm{l}$ of $\mathrm{dH}_{2} \mathrm{O}$. Samples were brought to a final volume of $45 \mu \mathrm{l}$ in $25 \mathrm{mM}$ Hepes, $0.75 \mathrm{mg} \mathrm{ml}^{-1}$ tRNA (Sigma), $3 \times$ saline sodium citrate (SSC), and $0.2 \%$ sodium dodecyl sulphate (SDS). Samples were boiled for $1 \mathrm{~min}$, allowed to cool to room temperature, and then applied to microarray slides. Hybridizations were conducted for $18 \mathrm{~h}$ at $65^{\circ} \mathrm{C}$ in hybridization chambers (Genetix). After hybridization, slides were washed gently by immersion in $1 \times$ $\mathrm{SSC}$ and $0.1 \% \mathrm{SDS}$ for $10 \mathrm{~min}$ at $45^{\circ} \mathrm{C}$ with gentle agitation to remove unbound dye. Slides were then washed gently in $0.1 \times \mathrm{SSC}$ for $10 \mathrm{~min}$ at room temperature, dipped 5 times in $0.06 \times \mathrm{SSC}$ wash solution, and dried by centrifugation at $600 \mathrm{rpm}$ for $5 \mathrm{~min}$. The slides were scanned on an AXON GenePix 4000B microarray scanner (Axon Instruments, Molecular Devices). Furthermore, dye swap analysis was performed for each sample used in this analysis to assess possible dye affects that could bias the analysis. Microarray data from the 40 arrays used in this experiment were extracted using GenePix Pro 4.0 software and the ratio of Cy5 to Cy3 fluorescence was quantified for each spot on the arrays (Axon Instruments).

Normalization and statistical analysis of microarray data. For each array, spatial- and intensity-based trends in the data were removed by Lowess normalization using Acuity 4.0 software. One-way ANOVA was used to identify genes for which the inter-individual variation within a collection site did not differ by $>2 \mathrm{SD}$ of the median fluorescence ratio ( $\mathrm{n}=10$ arrays). In addition, only those genes that displayed a signal to noise ratio (SNR) of $\geq 3$ and displayed at least a 2 -fold change in expression levels relative to the median log ratio (635:532) of laboratory-acclimated reference samples were included in the analysis. The 2-fold change in expression as a threshold for consideration is a conservative convention employed in many transcriptprofiling studies (Gracey et al. 2001, Podrabsky \& Somero 2004, van der Meer et al. 2005, Buckley et al. 2006). To directly compare the ratio of fluorescent intensity of sites to each other and not a reference pool, the median log ratios (635:532) of fluorescence intensities for each site were then normalized against a single experimental site (SH-OR). This method of normalizing fluorescence values in spatial experiments is similar to that used for time-course experiments in which reference samples are employed (see Podrabsky \& Somero 2004, Buckley et al. 2006). Lastly, principal component analysis (PCA) was performed using the Acuity 4.0 software to determine the cumulative separation between sites as a function of the numerous gene level responses. Since trends are easier to see in 2-dimensional representations, only component loadings for the first 2 principal components were used in plot ordination.

Quantitative PCR. To validate the microarray results, we performed targeted quantitative, real-time polymerase chain reaction ( $\mathrm{qPCR}$ ), a method which provides a highly sensitive and quantified measure of the expression levels of the mRNA of interest. We measured the expression levels of the constitutive heat shock protein $h s c 71$ and the inducible form hsp70, 2 genes commonly employed in studies assessing thermal stress in intertidal organisms. We chose to use 
these 2 particular genes due to the wealth of information on the physiological response of these genes in mussels. In addition, including $h s p 70$ in the $\mathrm{qPCR}$ allowed us to verify that the response being measured was not a result of a recent stressful insult; the remnants of which would be evident in this highly sensitive assay. Expression levels of these genes were normalized to a 'house keeping' gene, elf- $\alpha$, to correct for loading error and uniformity of the RT reaction. Briefly, $100 \mathrm{ng}$ of total RNA was reverse transcribed using a StrataScript cDNA synthesis kit with oligo dT primers (Stratagene) following the manufacturer's protocol. Quantitative real-time PCR reactions were performed with $2 \mu \mathrm{l}$ of cDNA synthesis product in $20 \mu \mathrm{l}$ SYBR green supermix (Bio-Rad). The PCR was run for 40 cycles with the following cycle parameters: $10 \mathrm{~s}$ at $94^{\circ} \mathrm{C}$ and $10 \mathrm{~s}$ at $58^{\circ} \mathrm{C}$. The primer concentrations $(0.5 \mu \mathrm{M})$ were empirically determined based on lowest $C_{t}$ values and highest efficiencies. Fluorescence threshold values were set at levels to maximize PCR efficiency, and only reactions with efficiencies within 90 to $110 \%$ were analyzed. Five, 5-fold serial dilutions of a single experimental sample from each PCR plate were used as a standard curve to calculate PCR efficiency. Melt curve analysis was performed following each PCR to confirm that only a single product was amplified. The sequences of the primers used for the qPCR analysis are reported in Table 2.

Emersion estimates. Ideally, our collections would have been correlated with detailed environmental measurements at these sites; unfortunately, we were not able to obtain the expected temperature data from locations close to our collection sites. As a proxy for differences in the environmental conditions at the sites, we estimated the cumulative amount of time (min) the mussel beds used in this study were emersed during the daylight hours of the month preceding our collection at each site. Using the T-Tide toolbox for Matlab (Pawlowicz et al. 2002), we calculated the total amount of time that the still water level at each site was below several tide heights $(0.25$ or $0.5 \mathrm{~m}$ above mean low low water [MLLW]) during the hours from 11:00 to 17:00

Table 2. Sense and anti-sense sequence of primer pairs used to amplify cDNA for $h s p 70, h s c 71$, and elf- $\alpha$ from $M$. californianus during quantitative polymerase chain reaction

\begin{tabular}{|ll|}
\hline Primer & Sequence \\
\hline hsp70 (sense) & 5'-CTTGTTGGTGATGCAGCTAAAAA-3' \\
hsp70 (anti-sense) & 5'-TTGGCATCGAAGATTGTATTTGA-3' \\
hsc71 (sense) & 5'-TGCCTTCACAGACACCGAAA-3' \\
hsc71 (anti-sense) & 5'-GACTGGGTTCATTGCCACTTG-3' \\
elf- $\alpha$ (sense) & 5'-GCATCTGGTACTGGTGAGTTTGAA-3' \\
elf- $\alpha$ (anti-sense) & 5'-AGGGCGTGTTCTCTTGTCTGA-3' \\
& \\
\hline
\end{tabular}

during the 30 or 60 d before our samples were collected (Fig. 2). These hours were chosen to incorporate the warmest hours of the day. The choice of tide heights was arbitrary, but gives a sense for the variation in low tide at the sites. Our choice to limit the emersion estimates to 30-60 d prior to collection was based on previous work performed on the physiological response of Mytilus spp. gill tissue to temperature acclimation. In the study by Buckley et al. (2001), they report a significant shift in the physiological response of heat shock protein (HSP) expression within 6 wk of acclimation. In addition, monthly monitoring of HSP protein levels in Mytilus revealed changes in protein levels over the period of a single month (P. Halpin pers. comm.).

\section{RESULTS}

The goal of this study was to employ large-scale gene expression profiling to explore a range of physiological pathways across large spatial scales in populations of the intertidal mussel Mytilus californianus. Previous studies measuring environmental variation within the habitat occupied by these invertebrates indicate they may display complex physiological responses along the latitudinal distribution of this species that does not vary linearly with latitude.

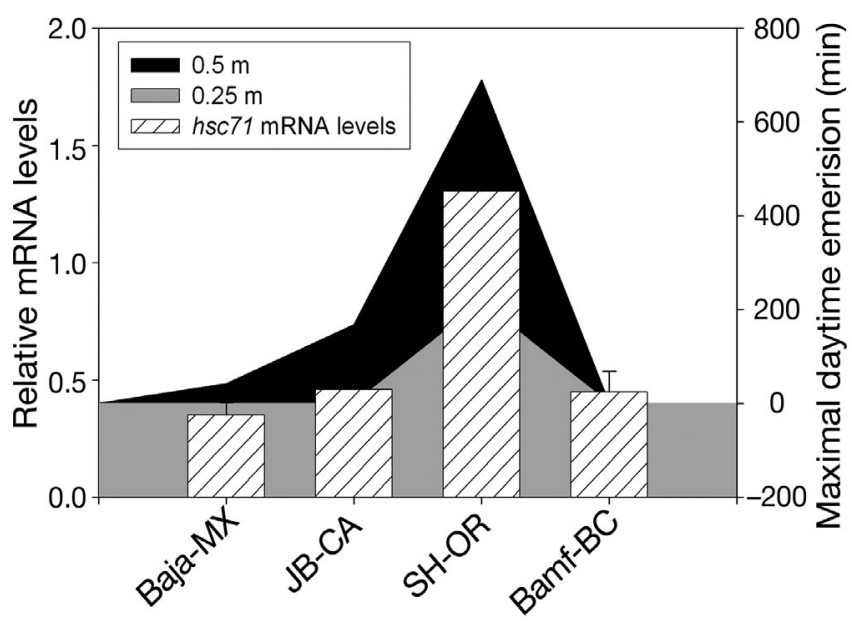

Fig. 2. Correlation between emersion times and hsc71 transcript levels. The relative (mean \pm SEM) levels of hsc71 mRNA (hatched bars, left $y$-axis), as determined by qPCR analysis, in gill tissues sampled from 4 sites along the west coast of North America (see Table 1). The maximal amount of time (minutes tide below threshold level) (filled areas, right $y$-axis) between 11:00 and 17:00 h mussel beds inhabiting the intertidal zone $0.25 \mathrm{~m}$ above mean low low water (MLLW) (light grey area) or $0.5 \mathrm{~m}$ above MLLW (black area) could potentially be exposed to ambient air temperatures for the $30 \mathrm{~d}$ preceding collection 


\section{Microarray analysis}

Utilizing a 2496 feature cDNA microarray, we generated transcriptome profiles for 5 ind. sampled from 4 sites spanning $17^{\circ}$ of latitude along the west coast of North America (Fig. 1, Table 1). To assess whether these expression profiles could be used as a basis to discriminate between gill tissue sampled from individuals collected at the various sites, we performed a PCA on the entire gene set. As can be seen in Fig. 3, the expression pattern in gill tissue sampled from individuals collected at SH-OR can be clearly distinguished from individuals sampled at JB-CA and Bamf-BC in both Component 1 (38.14\% of the variability) and Component 2 (9.41\% of the variability). Component 1 also distinguished between samples obtained from SH-OR and Baja-MX; however, this distinction was less clear. There was no distinction between SH-OR and Baja-MX in Component 2. Analysis of the major factors comprising the top 3 components, which account for $53.24 \%$ of the cumulative variation, revealed numerous cellular pathways that contribute significantly to the variation between sites (Figs. 4A \& 5A). These pathways were comprised of 1266 unique features that were chosen for further consideration in this study after normalization and statistical analysis using the Acuity 4.0 software package. Of these 1266 unique features, 324 showed at least a 2 -fold change in the mean relative expression for at least 1 site. This represents approximately $12 \%$ of the total features on the array. These results are similar to the percentage of genes shown to vary during genome-wide analysis of the physiological response to thermal acclimation in other metazoans (e.g. Podrabsky \& Somero 2004). Furthermore, we found the magnitude of variation, as well as the genes involved, did not follow a linear pattern. In fact, as had been predicted in the study by Helmuth et al. (2002), samples obtained

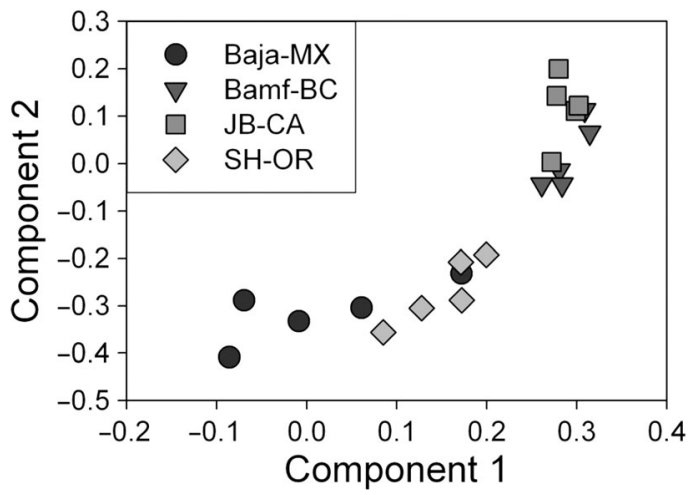

Fig. 3. Principle component analysis of the cumulative separation between collection sites as a function of gene level responses. Plot ordination was performed for the first 2 component loadings-Component 1: $X$-axis (38.14\% of the variation); Component 2: $y$-axis (9.41\% of the variation). For site definitions see Table 1 from the $\mathrm{SH}-\mathrm{OR}$ population showed a large degree of up-regulation in numerous genes, and, more specifically, many genes that may play a role in an organism's stress response (Figs. $4 \& 5$ ).

\section{Gene annotation}

The genes that displayed $\geq 2$-fold change in expression in 1 or more sites, and whose sequence had been determined at the time of this report, were clustered into a wide group of cellular functions based upon their 'biological process' classification given in the Gene Onotology (GO) and GeneCards (GC) annotation databases. Figs. 4A and 5A list the relevant gene clusters identified in this analysis, the function of which can be mapped to the following 12 cellular processes: (1) cell cycle regulation/cell proliferation, (2) protein rescue/ protein folding, (3) cell signaling, (4) protein degradation, (5) carbohydrate metabolism, (6) lipid metabolism, (7) apoptosis, (8) cell adhesion, (9) transcriptional regulation, (10) protein biosynthesis/modification, (11) cellular trafficking, and (12) cytoskeletal structuring/ reorganization. The potential relevance of these processes and the roles they may play in defining phenotypic variation will be addressed further in the discussion that follows.

\section{Biogeographic comparison}

To directly compare the expression levels of mussels sampled from Baja-MX, JB-CA, and Bamf-BC populations to those obtained from SH-OR, we further normalized the mean log ratio of each individual site to the mean log ratio of SH-OR samples. This method of normalizing fluorescence values is similar to that used for time-course experiments in which a reference RNA pool is utilized (see Podrabsky \& Somero 2004, Buckley et al. 2006). Gene expression ratios for several interesting genes were significantly higher in SH-OR samples when compared to samples obtained from JB-CA and Bamf-BC. Several genes associated with cellular stress response showed particularly high levels of expression in SH-OR samples. Relative levels of hsc71 transcript, a constitutively expressed heat shock protein, were 16fold higher in SH-OR samples compared to samples taken from California (SH-OR:JB-CA) and a 9-fold increase compared to samples taken in British Columbia (SH-OR:Bamf-BC) (Fig. 4C). Similarly, expression levels for the beta subunit of the proteasome complex showed a 6-fold and 11-fold increase over JB-CA and Bamf-BC samples, respectively (Fig. 4C). Relative levels of transcript for an integral membrane protein that functions in the maintenance of cell wall integrity and stress re- 
A Gene clusters

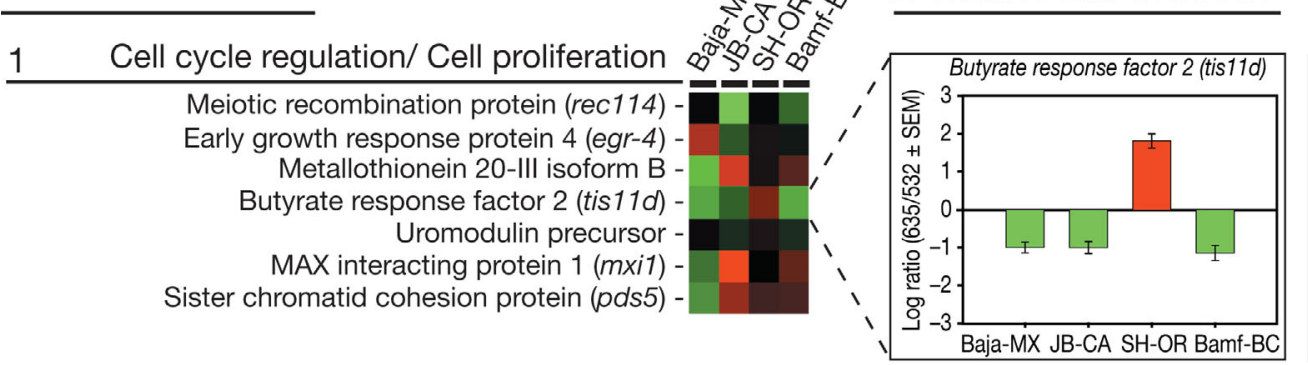

$2 \quad$ Protein rescue/ Protein folding Heat shock cognate $71 \mathrm{kDa}$ (hsc71) Heat shock cognate $71 \mathrm{kDa}$ (hsc71) Heat shock protein $90 \mathrm{kDa}(h s p 90)$ Heat shock protein $90 \mathrm{kDa}(h s p 90)$ Heat shock protein $83 \mathrm{kDa}$ (hsp83) -

$3 \quad$ Cell signaling Tyrosine-protein kinase transmembrane receptor Brain-specific angiogenesis inhibitor 3 Dual specificity protein phosphatase Leukocyte surface antigen (cd53) Insulin-like growth factor 2 receptor -
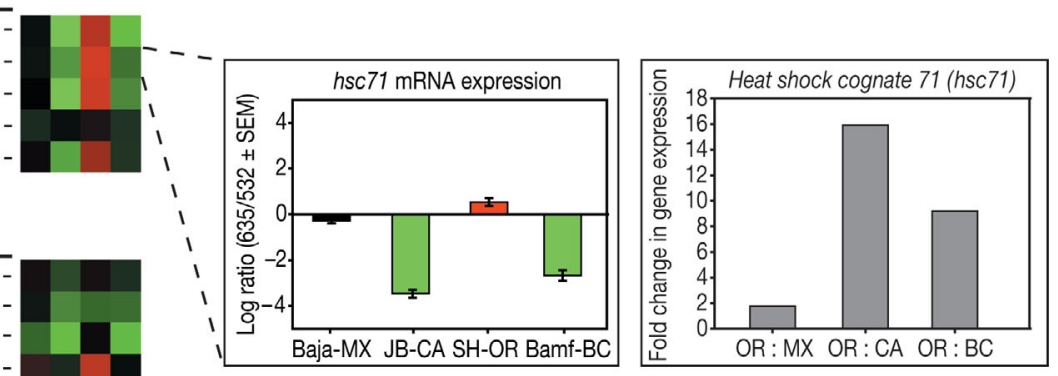

4 Protein degradation Phospholipase A2 Ubiquitin Proteasome subunit beta type 1B Proteasome subunit beta type 2 Ubiquitin -

Proteasome subunit alpha type 3 $26 \mathrm{~S}$ proteasome regulatory subunit 8 $26 \mathrm{~S}$ proteasome non-ATPase regulatory subunit $26 \mathrm{~S}$ proteasome regulatory subunit $6 \mathrm{~B}$ Ubiquitin
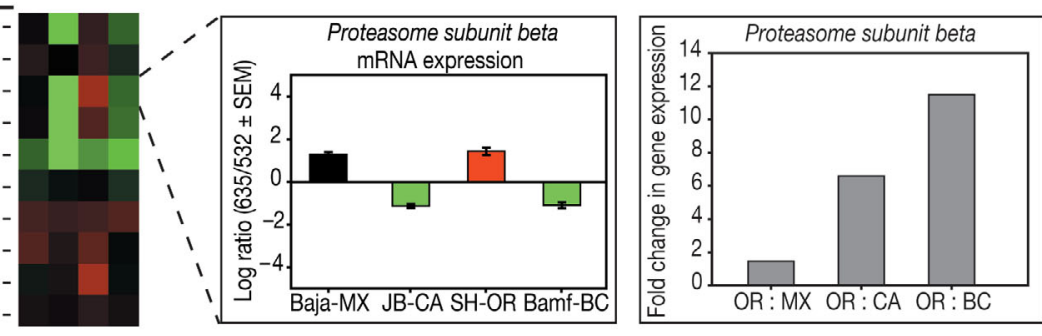

5

Carbohydrate metabolism Arginine kinase Amine oxidase 3-hydroxyisobutyryl-coenzyme A hydrolase Glycogen debranching enzyme Probable oxidoreductase $\mathrm{NADH}$-ubiquinone oxidoreductase chain 5 Thioredoxin Oxidoreductase $\mathrm{NADH}$-ubiquinone oxidoreductase

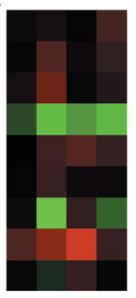

6
Lipid metabolism

Low-density lipoprotein receptor Epididymal secretory protein E1 precursor Low-density lipoprotein receptor Ganglioside GM2 activator precursor -

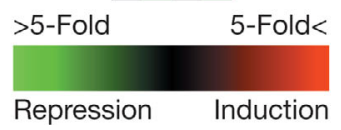

Fig. 4. Mytilus californianus. Gene expression profiles of gill tissue sampled from field-acclimatized $M$. californianus across its biogeographic distribution. (A) Gene Clusters 1 to 6 , grouped according to their biological function classification. Each row represents the expression profile of each gene in gill tissue sampled from 4 distinct populations (for definitions see Table 1). (B) Relative level (mean $\log _{2}$ ratio 635:532) of transcript measured in samples from each site compared to a reference RNA pool. (C) Direct comparison of the relative level of transcript measured in gill tissue sampled from mussel populations in SH-OR to the level of transcript measured in gill tissue sampled from mussel populations Baja-MX (OR:MX), JB-CA (OR:CA), and Bamf$\mathrm{BC}(\mathrm{OR}: \mathrm{BC})$ sponse pathways in yeast ( WSC2) also showed moderate increases over JB-CA and Bamf-BC samples, with a 2-fold and 3-fold increase, respectively (Fig. 5C). This expression trend is further highlighted by the relative expression of elf2- $\alpha$, a stress-regulated translation initiation factor in the endoplasmic reticulum, which displayed a 5-fold and 4 -fold increase in relative expres- sion over JB-CA and Bamf-BC samples, respectively (Fig. 5C). Fig. 5A to $\mathrm{C}$ also shows the expression profile of a $28 \mathrm{~S}$ ribosomal subunit, the expression of which was highly similar across all 4 sites. The lack of variation in this typically non-environmentally responsive gene family is an important point of validation for the expression profiles reported here. This further verifies that the 
A Gene clusters Cell wall integrity/ stress response protein (wSC2) -
Cytochrome p450 -

8 Calcineurin B subunit

Collagen alpha $3(\mathrm{VI})$ chain precursor Collagen alpha 1(XIV) chain precursor Transmembrane cell adhesion receptor $\mu$ Integrin alpha-PS2 precursor Collagen alpha $3(\mathrm{VI})$ chain precursor Polycystin-1L1 Ependymin precursor Collagen alpha 3(VI) chain precursor Collagen alpha $3(\mathrm{VI})$ chain precursor

$9 \quad$ Transcriptional regulation

Micronuclear linker his DNA topoisomerase II AF-10 protein Transcription intermediary factor 1 -gamma $60-\mathrm{kDa}$ SS-A/Ro ribonucleoprotein Ankyrin repeat and SOCS box containing Chromatin assembly factor 1 subunit $A$ -

10 Protein biosynthesis/ modification $40 S$ ribosomal protein $s 7$ DEAD box polypeptide 18 uga suppressor tRNA-associated antigenic protein Eukaryotic translation initiation factor 3 Protein pro1854 -

Zinc finger DHHC domain containing protein uga suppressor tRNA-associated antigenic protein $28 \mathrm{~S}$ ribosomal protein $\mathrm{s} 18 \mathrm{a}$

11

Cellular trafficking Intracellular protein transport protein Intracellular protein transport protein -
Signal recognition particle $54 \mathrm{kDa}$ protein (srp54) -
Mitochondrial carnitine/acylcarnitine c Mitochondrial carnitine/acylcarnitine c Signal recognition particle $54 \mathrm{kDa}$ (srp54) Gliacolin precursor (C1q-like protein) Vacuolar protein sorting-associated protein -
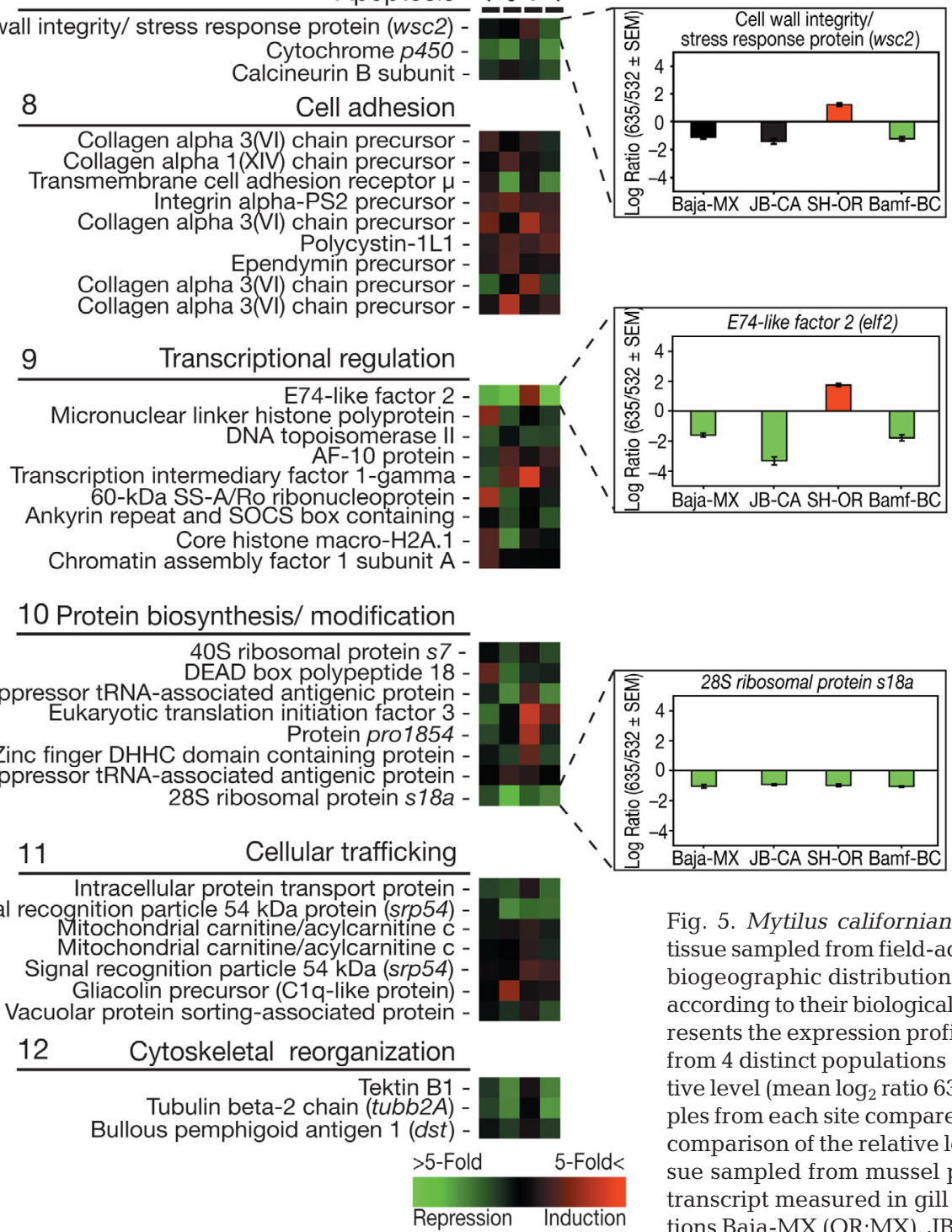

variation in expression seen in this study is not simply due to an effect of temperature on general transcriptional rates in these mussels or a sampling artifact.

\section{qPCR analysis}

As a means to confirm one of the major patterns apparent in the microarray data, we performed qPCR on 2 HSP genes commonly assayed in studies assessing thermal stress, hsc71 and hsp70. The average relative level of expression for each individual sampled was normalized to elf- $\alpha$ and then averaged according to site (Fig. 6). The results shown in Fig. 6 illustrate that


$\underline{\text { C Fold expression change }}$

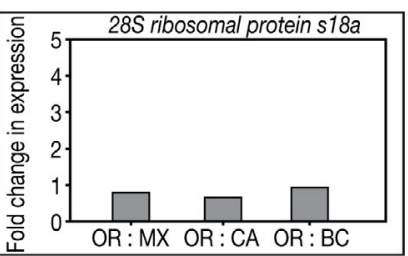

Fig. 5. Mytilus californianus. Gene expression profiles of gill tissue sampled from field-acclimatized $M$. californianus across its biogeographic distribution. (A) Gene Clusters 7 to 12, grouped according to their biological function classification. Each row represents the expression profile of each gene in gill tissue sampled from 4 distinct populations (for definitions see Table 1). (B) Relative level (mean $\log _{2}$ ratio 635:532) of transcript measured in samples from each site compared to a reference RNA pool. (C) Direct comparison of the relative level of transcript measured in gill tissue sampled from mussel populations in SH-OR to the level of transcript measured in gill tissue sampled from mussel populations Baja-MX (OR:MX), JB-CA (OR:CA), and Bamf-BC (OR:BC)

expression of the $h s p 70$ gene was negligible, detectable at any quantity in only a single individual (from $\mathrm{SH}-\mathrm{OR})$. This is in agreement with the microarray analysis as hsp 70 transcript was not detected above the 3 -fold SNR threshold in any of the arrayed samples. Expression of the $h s c 71$ gene, while variable, did display clear site-specific patterns that mirrored the pattern of expression identified for this gene in the microarray analysis (Fig. 6). The relative expression level of hsc71 was not statistically different between populations sampled from Baja-MX, JB-CA, and Bamf$\mathrm{BC}$, but expression levels in mussels sampled from $\mathrm{SH}-$ OR had hsC71 levels that were significantly higher than those at any other site (Fig. 6) (ANOVA, p < 0.05). 


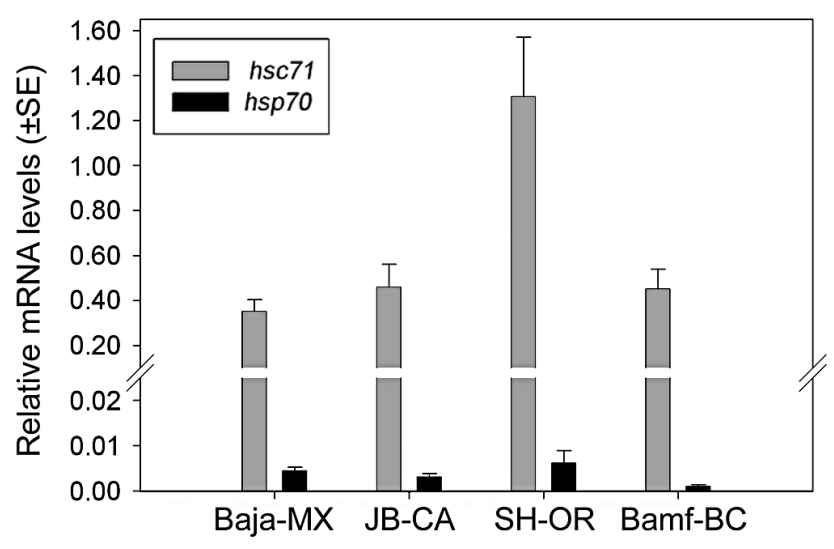

Fig. 6. Mytilus californianus. qPCR analysis of the relative levels (mean + SEM) of hsc71 mRNA (grey) and hsp70 mRNA (black) in gill tissues sampled from 4 sites along the west coast of North America. For site definitions see Table 1

\section{Emersion estimation}

Our calculations of the timing of tidal emersion provide a proxy for the length of time mussel beds at these locations were subjected to stressful environmental conditions. The minutes the tide spent lower than $0.5 \mathrm{~m}$ above MLLW during the month before collection correlated strongly with the expression levels of the heat shock protein hsc71 (Fig. 2).

\section{DISCUSSION}

In this study, we used a cDNA microarray to profile gene expression in the intertidal mussel Mytilus californianus across a large portion of this species' reported biogeographic range (Morris et al. 1980). Our results indicate that the physiological response of this intertidal invertebrate varied with latitude in such a way that there is not a gradient effect from north to south. Rather, we provide evidence for a mosaic of environmental conditions across this species range, similar to observations made for body temperatures in M. californianus (Helmuth et al. 2002, 2006). In addition, these data highlight the physiological responses of intertidal mussels to abiotic stressors in their environment, and the expression patterns observed in the mussels match patterns that have been observed in other marine metazoans. Thus, from a broad perspective, this study demonstrates the kind of linkage that can be made between macroecology and genomics in a marine study system. Moreover, our study is an example of how genomic tools can serve to integrate the macroecological and physiological perspectives. Below, we first present our findings in terms of gene expression profiling, and then discuss findings relative to previous ecological research on $M$. californianus.
This study is preceded by other research in experimental biogeography where gene expression of single genes was examined as a means to assess physiological response to the marine environment (e.g. Place et al. 2004, Somero 2005, Lovett et al. 2006, Todgham et al. 2006, Bystriansky et al. 2007). For example, expression analysis has been used to examine the physiological response of gill tissue during acclimation of euryhaline fishes to freshwater. Bystriansky and colleagues identified a significant transcriptional up-regulation of gill $\mathrm{Na}^{+} \mathrm{K}^{+}$ATPase mRNA that occurred during migration of Arctic char from seawater to freshwater (Bystriansky et al. 2007). Gene expression analysis has also shed significant light on the complex relationship between temperature stress and geographic ranges of intertidal organisms. Gene expression analysis of temperature induction profiles of subtidal populations of the sea urchin Strongylocentrotus purpuratus showed the thermal variation experienced by this species is sufficient to alter gene expression across the biogeographic distribution of S. purpuratus (Osovitz \& Hofmann 2005). This study also highlighted the natural plasticity of the thermal stress response characterized by a shift in onset temperature in laboratory-acclimated individuals (Osovitz \& Hofmann 2005). Lastly, although a study performed at the level of a gene product, the comparison of Hsp70 protein levels in broadly distributed populations of Nucella ostrina and Mytilus californianus showed a complex pattern of variation that does not correlate to latitudinal distribution (Sagarin \& Somero 2006).

In the present paper, we have investigated the transcriptional state of Mytilus californianus on a genomewide scale. A unique attribute of employing this type of approach is the ability to group the expression of related genes and assess the integrated response of multiple cellular functions. Utilizing the formation of gene clusters based on 'biological processes,' we provide a snapshot into the physiological state of mussel populations sampled in this study at a particular point in time when previous ecological work suggests they should be stressed by environmental conditions (Helmuth et al. 2002, 2006). Additionally, these analyses form a basis from which to draw comparisons at the organismal level with a number of previous studies that have assessed the physiological response of metazoans to various abiotic stressors. Although many genes altered their expression below the 2-fold threshold and these changes could have important biological effects, we chose to limit our discussion here to just a few gene clusters that display significant variation, in order to provide a context with which to discuss the potential relevance of these processes and the roles they may play in defining phenotypic variation. We survey a suite of these key clusters and discuss the potential insights they provide into the physiological state of the organisms. 


\section{Cell cycle regulation/cell proliferation (Cluster 1)}

In an effort to cope with the energetic costs of a stressful environment, organisms may delay or even arrest cellular proliferation and growth. On average, mussels sampled from SH-OR displayed a pattern of gene expression that indicates a lower level of cellular proliferation is occurring in this population of mussels. For example, early growth response protein $4(\mathrm{egr}-4)$ is strongly repressed in the gill tissue of $\mathrm{SH}-\mathrm{OR}$ mussels. Egr-4 activates the transcription of target genes whose products are required for mitogenesis and differentiation (Tourtellotte et al. 1999). While egr-4 is also repressed to some extent in Bamf-BC and JB-CA samples, it is, in fact, strongly induced in mussels sampled from Baja-MX (Fig. 4A). Alternatively, butyrate response factor 2 (tis11d) is repressed in all populations except $\mathrm{SH}-\mathrm{OR}$, where it is strongly up-regulated (Fig. 4A to C). Tis11d is a protein involved in regulating the response to growth factors by promoting the deadenylation and degradation of tumor necrosis factor $\alpha$ (TNF- $\alpha$ ) (Hudson et al. 2004), a potent cytokine that plays an important role in cell proliferation, differentiation, and apoptosis (Baud \& Karin 2001). Similar effects of environmental stressors on cell growth have been observed for the marine goby Gillichthys mirabilis when subjected to hypoxic stress (Gracey et al. 2001) and for tissue-specific responses to temperature (Buckley et al. 2006). Although an arrest in cell division may have been expected, since mussels are believed to be quiescent during low tide (the time at which samples were obtained for this study), the expression profiles of the genes identified in this functional cluster point out that there are gradients of activity. For example, mussels sampled at low tide in Baja-MX show signs of active cell proliferation, while the gene expression profile of the gill tissue samples from SH-OR are consistent with the inhibition of cell growth and proliferation (Fig. 4A).

\section{Protein rescue/protein folding (Cluster 2)}

The most highly up-regulated genes on the array belonged to the family of molecular chaperones, a group of proteins that primarily function to maintain protein homeostasis within the cell by assisting in the folding of nascent polypeptides. In addition, molecular chaperones play a pivotal role in maintaining protein homeostasis during cellular exposure to proteotoxic stressors such as heat or heavy metals by interacting with stress-denatured proteins and preventing their aggregation and/or degradation (Parsell \& Lindquist 1993). In response to a number of cellular insults, several members of this family known as heat shock proteins (HSP) are rapidly up-regulated and preferentially translated in a phylogenetically conserved 'heat shock response' (Lindquist 1986). Some HSPs, such as Hsp40 and Hsc71/Hsp70, directly interact with the hydrophobic regions of misfolded proteins, preventing them from forming aggregates (Fink 1999) that can potentially become cytotoxic (Bucciantini et al. 2002). More specialized members of the family, such as Hsp108, have the ability to disassociate large protein aggregates, which can then be re-folded or shuttled down the proteolytic pathway (Parsell et al. 1994).

Three of the 4 specific size classes of HSPs identified on the array showed increased levels of expression in mussels sampled from $\mathrm{SH}-\mathrm{OR}$ as compared to all other sites (Fig. 4A). hsc71, hsp83, and hsp90 all show a distinct increase in the level of transcript in SH-OR samples, with hsc71 transcript being expressed at the highest levels. Gill tissue sampled from mussels in SH-OR displayed a 16-fold and 9-fold higher level of expression when compared to JB-CA and Bamf-BC, respectively (Fig. 4C). Expression of hsp90 appears to be inconsistent, with 1 of 2 features identified as ' $h s p 90^{\prime}$, showing decidedly up-regulated expression in $\mathrm{SH}-\mathrm{OR}$ samples at levels similar to that seen for hsc71 and the second feature for hsp90 showing no variation across sites (Fig. 4A). However, it is very plausible the differential expression of hsp90 seen in the array is due to the presence of 2 separate isoforms; the inducible isoform, $h s p 90 \alpha$, and the constitutively expressed isoform, $h s p 90 \beta$ (as is the case for hsc71/hsp 70). Unfortunately, we currently do not have enough sequence information from these clones to distinguish between the 2 separate isoforms at this time and, thus, are prevented from drawing any further conclusions about the nature of the expression differences seen for these genes. Similar gene expression patterns for the constitutive transcripts of $h s c 70$ and $h s p 90$ were reported by Podrabsky \& Somero (2004) in the annual killifish. Transcripts for these genes were only mildly induced from several rounds of temperature cycling; however, when killifish were subjected to chronically elevated temperatures, both hsc70 and hsp90 were strongly upregulated (Podrabsky \& Somero 2004). Of the 4 HSPs currently known to be present on the array, only the highly inducible $h s p 70$ isoform of the $70 \mathrm{kDa}$ family was not detected in any of the arrayed mussels. Under conditions of acute stress, the rapid increase and subsequent return to basal levels of inducible transcripts (hsp70/hsp90 $\alpha$ ) are highly dynamic events. In porcelain crabs, hsp 70 levels can increase 25 -fold within the first hour of recovery from acute heat shock, while $h s p 90 \alpha$ can increase 5-fold within the same time frame (Teranishi \& Stillman 2007). Similarly, hsp70 and hsp90 $\alpha$ show a 19-fold and 11-fold increase, respectively, in tissues of a marine goby after a $2 \mathrm{~h}$ heat shock (Buckley et al. 2006). These studies suggest the re- 
sponse of these chaperones to temperature cycling and chronic temperature stress are distinct and are distinguished by the relative level of constitutive versus inducible transcript present, providing a signature for populations experiencing chronic temperature stress. Interestingly, in our study, neither the microarray analysis, nor the more sensitive qPCR analysis, detected a significant level of the inducible $h s p 70$ isoform (Fig. 6). The lack of detectible hsp 70 mRNA combined with the strikingly high levels of the constitutive isoform, hsc71, found within SH-OR mussel samples suggests the unique physiological phenotype displayed in the $\mathrm{SH}-\mathrm{OR}$ population is not in response to a single acute stressful event that immediately preceded the collection window. Rather, these results suggest the variation in expression patterns seen within this gene cluster may be the physiological signature of differential acclimatization amongst this population in response to seasonal differences in ambient exposure.

\section{Protein degradation (Cluster 4)}

Damaged proteins in the cell have 2 cellular fates. Moderately damaged proteins can often be rescued by the molecular chaperone pathway previously discussed. Alternatively, irreversibly damaged proteins are shuttled down the proteasome degradation pathway via covalent tagging with ubiquitin, a small, 76 amino acid protein. Conjugation of multiple ubiquitin molecules to polypeptides ('polyubiquitination') targets the damaged polypeptide for proteolytic degradation by the proteasome, a multi-subunit protein complex that binds the polyubiquitin chain and actively cleaves peptides. In the present study, we identified various components of the ubiquitin-proteasome pathway, including proteasome-associated proteins and subunits that show a complex expression pattern (Fig. 4A). Several beta subunits of the $26 \mathrm{~S}$ proteasome core complex were found to be expressed at greater levels in SH-OR populations; however, the inverse situation was found for an alpha subunit, psma3 (Fig. 4A). In Baja-MX and $\mathrm{SH}-\mathrm{OR}$ gill samples, proteasome subunit beta type $1 \mathrm{~B}$ (psmb1) was found to be expressed at equivalent levels; however, JB-CA and Bamf-BC populations displayed 6.5-fold and 11.4-fold lower expression, respectively (Fig. 4A to C). Likewise, proteasome subunit beta type 2 (psmb2) displayed similar expression patterns in these populations of mussels (Fig. 4A). Conversely, psma3 showed the exact opposite expression profile, with higher levels being recorded in JB-CA and BamfBC populations (Fig. 4A). These conflicting expression patterns may arise from the different roles for alphaand beta-type subunits, with the beta subunits serving solely as the catalytic subunits of the machinery (Bau- meister et al. 1998). Again, these data are in agreement with expression patterns identified in other marine species that incur irreversible protein damage when exposed to environmentally relevant temperature extremes. Both porcelain crabs (Teranishi \& Stillman 2007) and marine gobies (Buckley et al. 2006) show sustained up-regulation of genes involved in the ubiquitin-proteasome pathway at temperatures near the upper extremes experienced by each species.

In addition to the proteasome subunit beta transcripts, multiple regulatory protein transcripts were picked up in the arrayed samples (26S proteasome regulatory subunit $6 \mathrm{~B}$, subunit 8 , and the $26 \mathrm{~S}$ proteasome non-ATPase regulatory subunit). However, unlike the genes that encode for the proteasome complex itself, these regulatory genes show little variation between sites (Fig. 4A). Acclimation to chronically elevated temperatures has been shown to result in a weak response of proteasome regulatory subunits in killifish (Podrabsky \& Somero 2004). Conversely, these same genes appear to be highly responsive to short-term temperature cycling, indicating different regulatory mechanisms exist to balance protein turnover in the cell during temperature acclimation (Podrabsky \& Somero 2004). This complex pattern of expression is most likely due, in part, to the intricate mechanism of proteasome assembly, regulation, and action. For example, eukaryotic proteasomes contain 2 copies each of 14 different subunits, which, based on their sequence similarity, are divided into the noncatalytic $\alpha$ - and the catalytic $\beta$-type subunits (Baumeister et al. 1998). Furthermore, there is evidence that variation in the heterogeneity of the beta subunit may serve to regulate substrate specificity of the proteasome. Hochstrasser and colleagues found proteasomal populations with distinct subunit compositions can exist in the same cell in mammals. They show 3 variant $\beta$ subunits, $\operatorname{lmp} 2, \operatorname{lmp} 7$, and mecl1, are inducible by $\gamma$-interferon and can specifically replace homologous proteasome subunits during assembly of newly formed proteasomes (Hochstrasser 1995). These data taken together with the separate roles for the alpha and beta subunits indicate the general trends identified in this cluster of genes may reflect a shift in protein homeostasis that requires a greater need for compartmentalized proteolytic activity in the SH-OR population of mussels.

\section{Apoptosis (Cluster 7)}

In some cases, prolonged environmental stress may cause significant enough damage to the cellular machinery that repair mechanisms are insufficient to prevent cell death. Under these circumstances, several regulators of stress-responsive pathways can be modu- 
lated to shift their biological function to potentiate apoptosis in the cell. In general, this occurrence was not observed in this study. There was little variation in gene expression associated specifically with apoptosis observed in the gill samples from the 4 different populations; however, a putative cell wall integrity and stress response protein (wSC2) was up-regulated in SH-OR mussels (Fig. 5A to C). Members of the Wsc family of proteins are putative regulators of the Pkc1-Mpk1 pathway in yeast that functions in the maintenance of cell wall integrity and stress response pathways and may laterally activate pro-apoptotic pathways (Verna et al. 1997). These data suggest that, despite the strong expression of stress-responsive genes in the SH-OR population of mussels, the stressors were not sufficient enough to increase the level of apoptosis above steadystate cell maintenance. The increased expression seen in some gene families associated with apoptotis (i.e. wsc2, cytochrom p450) may indicate the mussels sampled from Baja-MX and SH-OR may be preparing to initiate an apoptotic response.

If the expression patterns of the gene clusters are viewed as an integrated response, they may be highlighting significant changes in the physiological response and may underscore environmental factors impacting the performance of Mytilus californianus. The physiological phenotype from the $\mathrm{SH}-\mathrm{OR}$ population is distinctly different when compared to the other 3 populations. In fact, of the other 3 populations sampled, the geographically distant Baja-MX population appears more similar with respect to gene expression (Fig. 3). Viewed at the organismal level and not just individual pathways, one can argue that the mussels in the SH-OR population display a distinct physiological phenotype that indicates a shift in energy allocation from growth and proliferation to active cellular defense and repair mechanisms in response to environmental stress.

These data may also begin to provide insight into the impact of aerial body temperatures on mussel growth patterns. While the positive correlation between sea surface temperature (SST) and mussel growth has been well established (Newell 1979, Behrens Yamada \& Peters 1988, Seed \& Suchanek 1992), to a large extent, we still know little about the physiological effects of aerial body temperature on mussel growth. A recent study assessing the spatial patterns of growth in Mytilus californianus near Point Conception identified a strong correlation between mean intertidal body temperature and growth rates at sites spanning the Point Conception geographic boundary (Blanchette et al. 2007). However, this study was unable to separate the effects of aerial versus seawater temperature, both of which contribute to the mean intertidal body temperature of mussels. Blanchette and colleagues speculate that the growth differences observed in their study were either due solely to the influence of SST on mean intertidal temperature, as generally expected for growth of marine invertebrates (Newell 1979), or that chronic exposure to overall cooler intertidal temperatures reduces growth rates at sites north of Point Conception. Our data suggest that aerial body temperature can, in fact, negatively impact growth in mussel populations that otherwise display relatively fast growth rates. These data would seem to lend support to the hypothesis that both aerial and seawater temperatures impact growth and that cumulative temperature exposure is the best predictor of growth rates across sites when nutrient availability is not limiting.

Overall, these expression patterns provide further empirical support for emerging models predicting the complexity of environmental conditions along the biogeographic range of these intertidal invertebrates (Helmuth et al. 2002, 2005, Sagarin \& Gaines 2002). Our previous understanding of the physiological response to thermal variation in these organisms and the expression data for several classes of HSP makes the strongest case between an environmental parameter and physiological function. By calculating the total minutes the tide levels were $0.5 \mathrm{~m}$ above MLLW during daylight hours in the month preceding our collection, a strong correlation can be drawn between emersion time and expression levels of the heat shock protein hsc71 (Fig. 2), thus, suggesting temperature may be a significant environmental factor driving the differential gene expression identified in this study. Although compelling, the role temperature plays in setting the phenotype of different populations is just one example of the strength of expression analysis across large spatial scales. With appropriate consideration, equally compelling analyses can potentially be made for multiple environmental parameters, as indicated by the diverse cellular pathways implicated in this study.

It should also be mentioned that this study represents only a snapshot of the physiological state of the organism collected at a single point in time. If the study were conducted at a different point in time, there is the potential that the physiological response could be reversed, signifying more stressful conditions at southern sites, or potentially identifying alternative mechanisms driving gene expression (e.g. food availability, gametogenesis). At the same time, this represents a powerful feature of this study; because our samples were gathered across latitudes in this snapshot fashion, our results emphasize geographic differences in expression, rather than the co-variation of factors due to time and distance. An analysis of the transcriptome over the course of an entire year will eventually reveal the ecological gradient experienced by these separate populations and highlight the interaction between physiological plasticity and environmental variation 
that establishes biogeographic patterning. A second caveat of this study is the lack of precise tidal height measurements for the collection sites. Unfortunately, as stated in the 'Materials and methods' section, we were unable to overcome the logistical barriers presented by simultaneously obtaining these precise measurements at remote sites. Since vertical limits of mussel beds are often set by both abiotic (e.g. wave splash in the upper limits) and biotic factors (e.g. predation in the lower limits), there can be considerable variation among sites with respect to distribution (Harley \& Helmuth 2003). This could complicate the interpretation of these analyses as the differences could be compounded by a difference in the absolute tidal height of the collection. However, we would predict, based on body temperatures across the vertical distribution at these sites (Helmuth et al. 2006) that this occurrence would only exaggerate the results, as opposed to a reversal, and that the overall trends seen in this study would remain the same. We are currently investigating this phenomenon by assessing the degree of inter-individual variation within the SH-OR population; however, this analysis is well beyond the scope of the present study.

\section{CONCLUSIONS}

Overall, the majority of genes identified in this study displayed an expression profile that varied as a function of collection site; however, this profile did not correlate linearly with the biogeographic distribution of this species, largely supporting the hypothesis of this study (Figs. 3 to 5). While physiological response to thermal variation across latitudes appears to be contributing significantly to the variation in gene expression, we currently cannot speculate on the importance of contributions from secondary parameters such as differences in nutrient availability, hypoxia, salinity, or predator abundance. Finally, our study on intertidal mussels exemplifies the usefulness of the new suite of molecular and genomic tools available to marine ecologists and provides an initial glimpse at the acclimatization signature for distinct populations of mussels under natural variation. Microarrays now being developed for non-model systems, such as Mytilus spp., will be an important tool, providing insight into the interplay between multiple cellular pathways and abiotic factors that ultimately result in a physiological phenotype, thus providing a backdrop for investigations at both cellular and organismal levels.

Acknowledgements. We thank all the members of the Hofmann Laboratory group for assistance with sample collection. We gratefully acknowledge A. Y. Gracey (University of South- ern California) for the construction of the mussel cDNA library used in this study while a PISCO-Postdoctoral Fellow in the laboratory of G. N. Somero (Hopkins Marine Station of Stanford University). In addition, S.P.P. was supported by a U.S. National Institutes of Health NIH-NRSA Postdoctoral Fellowship. The authors acknowledge the U.S. National Science Foundation for financial support during the course of this writing project (NSF Grant OCE-0425107 to G.E.H.). This is Contribution no. 276 from PISCO, the Partnership for Interdisciplinary Studies of Coastal Oceans funded primarily by the Gordon and Betty Moore Foundation and David and Lucile Packard Foundation.

\section{LITERATURE CITED}

Baud V, Karin M (2001) Signal transduction by tumor necrosis factor and its relatives. Trends Cell Biol 11:372-377

Baumeister W, Walz J, Zuhl F, Seemuller E (1998) The proteasome: paradigm of a self-compartmentalizing protease. Cell 92:367-380

Behrens Yamada SB, Peters EE (1988) Harvest management and the growth and condition of submarket-size sea mussels, Mytilus californianus. Aquaculture 74:293-299

- Bertness MD, Leonard GH, Levine JM, Bruno JF (1999) Climate-driven interactions among rocky intertidal organisms caught between a rock and a hot place. Oecologia 120:446-450

Blanchette CA, Helmuth B, Gaines SD (2007) Spatial patterns of growth in the mussel, Mytilus californianus, across a major oceanographic and biogeographic boundary at Point Conception, California, USA. J Exp Mar Biol Ecol 340:126-148

Bucciantini M, Giannoni E, Chiti F, Baroni F and others (2002) Inherent toxicity of aggregates implies a common mechanism for protein misfolding diseases. Nature 416:507-511

Buckley BA, Owen ME, Hofmann GE (2001) Adjusting the thermostat: the threshold induction temperature for the heatshock response in intertidal mussels (genus Mytilus) changes as a function of thermal history. J Exp Biol 204:3571-3579

Buckley BA, Gracey AY, Somero GN (2006) The cellular response to heat stress in the goby Gillichthys mirabilis: a cDNA microarray and protein-level analysis. J Exp Biol 209:2660-2677

Byers JE (2005) Quantifying geographic variation in physiological performance to address the absence of invading species. Ecoscience 12:358-365

Bystriansky JS, Frick NT, Richards JG, Schulte PM, Ballantyne JS (2007) Wild arctic char (Salvelinus alpinus) upregulate gill $\mathrm{Na}^{+}, \mathrm{K}^{+}$-ATPase during freshwater migration. Physiol Biochem Zool 80:270-282

Cunningham C, Hikima J, Jenny MJ, Chapman RW and others (2006) New resources for marine genomics: bacterial artificial chromosome libraries for the eastern and Pacific oysters (Crassostrea virginica and C. gigas). Mar Biotechnol 8:521-533

Dhar AK, Dettori A, Roux MM, Klimpel KR, Read B (2003) Identification of differentially expressed genes in shrimp (Penaeus stylirostris) infected with white spot syndrome virus by cDNA microarrays. Arch Virol 148:2381-2396

Dupont S, Wilson K, Obst M, Skold H, Nakano H, Thorndyke MC (2007) Marine ecological genomics: when genomics meets marine ecology. Mar Ecol Prog Ser 332:257-273

Fink AL (1999) Chaperone-mediated protein folding. Physiol Rev 79:425-449

Gracey AY, Troll JV, Somero GN (2001) Hypoxia-induced gene expression profiling in the euryoxic fish Gillichthys mirabilis. Proc Natl Acad Sci USA 98:1993-1998 
Harley CDG, Helmuth BST (2003) Local- and regional-scale effects of wave exposure, thermal stress, and absolute versus effective shore level on patterns of intertidal zonation. Limnol Oceanogr 48:1498-1508

Helmuth B, Harley CDG, Halpin PM, O'Donnell M, Hofmann GE, Blanchette CA (2002) Climate change and latitudinal patterns of intertidal thermal stress. Science 298:1015-1017

Helmuth B, Kingsolver JG, Carrington E (2005) Biophysics, physiological ecology, and climate change: Does mechanism matter? Annu Rev Physiol 67:177-201

- Helmuth B, Broitman BR, Blanchette CA, Gilman S and others (2006) Mosaic patterns of thermal stress in the rocky intertidal zone: implications for climate change. Ecol Monogr 76:461-479

Hochstrasser M (1995) Ubiquitin, proteasomes, and the regulation of intracellular protein-degradation. Curr Opin Cell Biol 7:215-223

- Hofmann GE, Place SP (2007) Genomics-enabled research in marine ecology: challenges, risks and pay-offs. Mar Ecol Prog Ser 332:249-255

Hofmann GE, Burnaford JL, Fielman KT (2005) Genomicsfueled approaches to current challenges in marine ecology. Trends Ecol Evol 20:305-311

Hudson BP, Martinez-Yamout MA, Dyson HJ, Wright PE (2004) Recognition of the mRNA AU-rich element by the zinc finger domain of TIS11d. Nat Struct Mol Biol 11: 257-264

Lester SE, Gaines SD, Kinlan BP (2007) Reproduction on the edge: large-scale patterns of individual performance in a marine invertebrate. Ecology 88:2229-2239

Levinton JS, Monahan RK (1983) The latitudinal compensation hypothesis - growth data and a model of latitudinal growthdifferentiation based upon energy budgets. 2. Intraspecific comparisons between subspecies of Ophryotrocha puerilis (Polychaeta, Dorvilleidae). Biol Bull 165:699-707

Lewis JR (1986) Latitudinal trends in reproduction, recruitment and population characteristics of some rocky littoral mollusks and cirripedes. Hydrobiologia 142:1-13

Lindquist S (1986) The heat-shock response. Annu Rev Biochem 55:1151-1191

Lovett DL, Verzi MP, Burgents JE, Tanner CA, Glomski K, Lee JJ, Towle DW (2006) Expression profiles of $\mathrm{Na}^{+}, \mathrm{K}^{+}$-ATPase during acute and chronic hypo-osmotic stress in the blue crab Callinectes sapidus. Biol Bull 211:58-65

Menge BA, Branch GM (2001) Rocky intertidal communities. In: Bertness MD, Gaines SD, Hay M (eds) Marine community ecology. Sinauer Association, Sunderland, MA, p 221-251

Morris RH, Abbott DP, Haderlie EC (1980) Intertidal invertebrates of California. Stanford University Press, Palo Alto, CA

Morrison RN, Cooper GA, Koop BF, Rise ML, Bridle AR, Adams MB, Nowak BF (2006) Transcriptome profiling the gills of amoebic gill disease (AGD)-affected Atlantic salmon (Salmo salar L.): A role for tumor suppressor p53 in AGD pathogenesis? Physiol Genomics 26:15-34

Newell CR (1979) Biology of intertidal animals. Marine Ecological Surveys, Faversham

> Osovitz CJ, Hofmann GE (2005) Thermal history-dependent expression of the hsp70 gene in purple sea urchins: biogeographic patterns and the effect of temperature acclimation. J Exp Mar Biol Ecol 327:134-143

Parmesan C, Yohe G (2003) A globally coherent fingerprint of climate change impacts across natural systems. Nature 421: $37-42$

> Parsell DA, Lindquist S (1993) The function of heat-shock

Initial editorial responsibility: Howard Browman, Storebø,

Norway (until November 5, 2007); Final editorial responsibility:

Matthias Seaman, Oldendorf/Luhe, Germany proteins in stress tolerance: degradation and reactivation of damaged proteins. Annu Rev Genet 27:437-496

Parsell DA, Kowal AS, Singer MA, Lindquist S (1994) Protein disaggregation mediated by heat-shock protein Hsp104. Nature 372:475-478

Pawlowicz R, Beardsley B, Lentz S (2002) Classical tidal harmonic analysis including error estimates in MATLAB using T_TIDE. Comput Geosci 28:929-937

$>$ Place SP, Zippay ML, Hofmann GE (2004) Constitutive roles for inducible genes: evidence for the alteration in expression of the inducible hsp70 gene in Antarctic notothenioid fishes. Am J Physiol Regul Integr Comp Physiol 287:R429-R436

Podrabsky JE, Somero GN (2004) Changes in gene expression associated with acclimation to constant temperatures and fluctuating daily temperatures in an annual killifish Austrofundulus limnaeus. J Exp Biol 207:2237-2254

Rodriguez-Lanetty M, Phillips WS, Weis VM (2006) Transcriptome analysis of a cnidarian-dinoflagellate mutualism reveals complex modulation of host gene expression. BMC Genomics 7:23

Sagarin RD, Gaines SD (2002) Geographical abundance distributions of coastal invertebrates: using one-dimensional ranges to test biogeographic hypotheses. J Biogeogr 29: 985-997

Sagarin RD, Somero GN (2006) Complex patterns of expression of heat-shock protein 70 across the southern biogeographical ranges of the intertidal mussel Mytilus californianus and snail Nucella ostrina. J Biogeogr 33:622-630

Seed R, Suchanek T (1992) Population and community ecology of Mytilus. In: The mussel Mytilus: ecology, physiology, genetics and culture. Elsevier, Amsterdam, p 87-169

Somero GN (2002) Thermal physiology and vertical zonation of intertidal animals: optima, limits, and costs of living. Integr Comp Biol 42:780-789

Somero GN (2005) Linking biogeography to physiology: evolutionary and acclimatory adjustments of thermal limits. Front Zool 2:1

Spicer JI, Gaston KJ (1999) Physiological diversity and its ecological implications. Blackwell Science, Oxford

Teranishi KS, Stillman JH (2007) A cDNA microarray analysis of the response to heat stress in hepatopancreas tissue of the porcelain crab Petrolisthes cinctipes. Comp Biochem Physiol D 2:53-62

Todgham AE, Iwama GK, Schulte PM (2006) Effects of the natural tidal cycle and artificial temperature cycling on Hsp levels in the tidepool sculpin Oligocottus maculosus. Physiol Biochem Zool 79:1033-1045

Tourtellotte WG, Nagarajan R, Auyeung A, Mueller C, Milbrandt J (1999) Infertility associated with incomplete spermatogenic arrest and oligozoospermia in Egr4-deficient mice. Development 126:5061-5071

van der Meer DL, van den Thillart GE, Witte F, de Bakker MA and others (2005) Gene expression profiling of the longterm adaptive response to hypoxia in the gills of adult zebrafish. Am J Physiol Regul Integr Comp Physiol 289:R1512-R1519

Verna J, Lodder A, Lee K, Vagts A, Ballester R (1997) A family of genes required for maintenance of cell wall integrity and for the stress response in Saccharomyces cerevisiae. Proc Natl Acad Sci USA 94:13804-13809

Wilson K, Thorndyke M, Nilsen F, Rogers A, Martinez P (2005) Marine systems: moving into the genomics era. PSZN I: Mar Ecol 26:3-16

Yamahira K, Conover DO (2002) Intra- vs. interspecific latitudinal variation in growth: Adaptation to temperature or seasonality? Ecology 83:1252-1262

Submitted: September 13, 2007; Accepted: November 22, 2007

Proofs received from author(s): January 28, 2008 